\title{
MENINGKATKAN HASIL BELAJAR BIOLOGI MENGGUNAKAN LKS WORD SQUARE DISERTAI PRAKTIK LABORATORIUM DI MTs Al-ASROR TAHUN PELAJARAN 2011/2012
}

\author{
Moh. Mu’arif \\ Achyani \\ Pendidikan Biologi FKIP Universitas Muhammadiyah Metro
}

\begin{abstract}
The aim of the research to implement of worksheet word square with laboratory practice are to improve study result of student in grade VIII at MTs Al-Asror year education 2011/2012 the subject matter living systems of plants. The method in this research was classroom action research and the subjeck of research is student at VIII MTS Al-Asror. The research indicated that more than $75 \%$ student can finish the examinition. The data gaided by observation and tes technique, and then analysed by using discriptif data analysed technique. The result of the analysis, showed that aim of worksheet word square with laboratory practice are to increase the study result of student.
\end{abstract}

Kata Kunci: model word square, praktik laboratorium, hasil belajar siswa.

Ilmu Pengetahuan Alam (IPA) merupakan ilmu yang berkaitan dengan cara mencari tahu tentang alam secara sistematis, sehingga IPA bukan hanya penguasaan kumpulan pengetahuan yang berupa fakta-fakta, konsep-konsep, atau prinsip-prinsip saja. Proses pembelajaranya adalah menekankan pada pemberian pengalaman langsung untuk mengembangkan kompetensi agar menjelajahi dan memahami alam secara alamiah.

Pengembangan Kurikulum Tingkat Satuan Pendidikan (KTSP) yang beragam mengacu pada standar nasional pendidikan untuk menjamin pencapaian tujuan pendidikan nasional. Depdiknas, (2006:3) "Standar nasional pendidikan terdiri atas standar isi, proses, kompetensi lulusan, tenaga kependidikan, sarana dan prasarana, pengelolaan, pembiayaan dan penilaian pendidikan.”

Dengan demikian pembelajaran IPA Terpadu (Biologi) harus bertumpu pada dua hal yaitu optimalisasi interaksi semua unsur pembelajaran dan optimalisasi keterlibatan seluruh siswa dalam pembelajaran. Seiring dengan arus perubahan dunia pendidikan di Indonesia, Depdiknas dalam Muhfahroyin, (2009:1) "Pada Tahun Pelajaran 2006/2007 Depdiknas meluncurkan Kurikulum Tingkat Satuan Pendidikan (KTSP).

Tidak maksimalnya hasil belajar siswa terhadap mata pelajaran IPA Terpadu dapat disebabkan oleh rendahnya minat belajar siswa yang disebabkan kurang aktifnya siswa dalam kegiatan pembelajaran. Hal ini sesuai pendapat Sudjana (2001) yang menyatakan bahwa "Metode pembelajaran yang tepat dapat mempertinggi hasil belajar siswa dalam pengajaran yang pada gilirannya dapat meningkatkan hasil belajar".

Penyelenggaraaan pendidikan akan dapat berhasil apabila semua unsur dalam sistem pembelajaran berjalan seiring dan seirama menuju tujuan pendidikan yang ditetapkan. Berkaitan 
dengan itu dalam pembelajaran yang tidak mengharuskan siswa menghafal fakta-fakta tetapi sebuah metode pembelajaran yang mendorong siswa untuk aktif dan berpikir kritis dalam belajar, dan menerapkan apa yang dipelajari dalam konteks nyata.

Salah satu upaya untuk meningkatkan hasil belajar adalah dengan menggunakan model pembelajaran LKS Word Square disertai praktik laboratorium. Kelebihan dari praktik laboratorium adalah siswa dilibatkan untuk turut berpikir sehingga emosi siswa dapat terlibat langsung dalam proses pembelajaran, meningkatkan keterampilan siswa melalui suatu kegiatan, dapat mengamati suatu proses/kejadian dengan sendirinya, sehingga akan memperkaya pengalaman dan meningkatkan serta meningkatkan serta membangkitkan rasa ingin tahu siswa.

\section{METODE}

Penelitian ini dilakukan pada MTs Al-Asror Sekampung Kabupaten Lampung Timur. Subjek penelitian adalah siswa kelas VIII. Penelitian ini dilaksanakan pada semester ganjil tahun pelajaran 2011/2012 dan berlangsung melalui dua siklus yang masing-masing siklus terdiri dari dua kali pertemuan.

Pelaksanakan tindakan dilakukan oleh peneliti dan observer sacra team work. Pada setiap kegiatan penelitian tahapan-tahapan yang dilakukan meliputi pendahuluan,kegiatan inti, dan diakhiri dengan penutup.

Tabel 1: Data peningkatan aktivitas siswa siklus I dan siklus II
Data yang diperlukan dalam penelitian ini adalah aktivitas siswa dalam proses pembelajaran serta hasil belajar siswa. Untuk memperoleh data penelitian tersebut adalah menggunakan lembar observasi dan tes. Lembar observasi untuk mengukur Kegembiraan dalam belajar. Kecepatan dan ketepatan Memperhatikan penjelasan guru.

Keterampilan menggunakan alat. (5) Kerjasama dalam kelompok. (6) Minat dan kreativitas siswa. (7) Sikap kritis dan ingin tahu.

Data hasil penelitian dianalisis menggunakan teknik analisa data secara deskriptif, yaitu dengan mendiskripsikan aktivitas siswa dan hasil belajar. Dengan penggunaan analisis secara deskriftif, secara otomotis dapat dipahami dan dimengerti apa yang yang menjadi kehendak peneliti yaitu tercapainya laporan tugas akhir yang mampu memberikan informasi kepada para pembaca.

\section{HASIL}

Data hasil penelitian aktivitas belajar siswa pada siklus. Selama proses pembelajaran diperoleh data tentang aktivitas siswa sebagaimana Tabel 1 . Aktivitas pembelajaran siswa yang telah terjadi dikelas memiliki pengaruh terhadap hasil belajar sebagaimana Tabel 2.

\begin{tabular}{|l|l|c|c|c|c|}
\hline \multirow{2}{*}{ No } & \multicolumn{2}{|c|}{ Aktivitas Siswa } & \multicolumn{2}{|c|}{ Siklus I } & \multicolumn{2}{c|}{ Siklus II } \\
\cline { 3 - 6 } & & Pertemuan 1 & Pertemuan 1 & Pertemuan 1 & Pertemuan 2 \\
\hline 1 & Kegembiraan dalam belajar. & $63 \%$ & $89 \%$ & $72 \%$ & $76 \%$ \\
\hline 2 & Kecepatan dan ketepatan. & $52 \%$ & $68 \%$ & $63 \%$ & $57 \%$ \\
\hline 3 & Memperhatikan penjelasan guru & $89 \%$ & $78 \%$ & $86 \%$ & $84 \%$ \\
\hline 4 & Keterampilan menggunakan alat. & $36 \%$ & $52 \%$ & $45 \%$ & $69 \%$ \\
\hline 5 & Kerjasama dalam kelompok. & $36 \%$ & $36 \%$ & $31 \%$ & $76 \%$ \\
\hline
\end{tabular}




\begin{tabular}{|l|l|c|c|c|c|}
\hline 6 & Minat dan kreativitas siswa. & $31 \%$ & $68 \%$ & $50 \%$ & $53 \%$ \\
\hline 7 & Sikap kritis dan ingin tahu. & $26 \%$ & $36 \%$ & $36 \%$ & $38 \%$ \\
\hline
\end{tabular}

Tabel 2. Hasil belajar siswa Siklus 1 dan Siklus 2

\begin{tabular}{|l|l|l|c|c|}
\hline No & Nilai & \multicolumn{1}{|c|}{ Kategori } & $\begin{array}{c}\text { Presentase } \\
\text { Siklus 1 }\end{array}$ & $\begin{array}{c}\text { Presentase } \\
\text { Siklus 2 }\end{array}$ \\
\hline 1 & $\geq 6.0$ & Tuntas & $68,42 \%$ & $76,927 \%$ \\
\hline 2 & $\leq 6.0$ & Tidak Tuntas & $31,58 \%$ & $23,08 \%$ \\
\hline \multicolumn{2}{|r|}{ Jumlah } & $100,00 \%$ & $100,00 \%$ \\
\hline
\end{tabular}

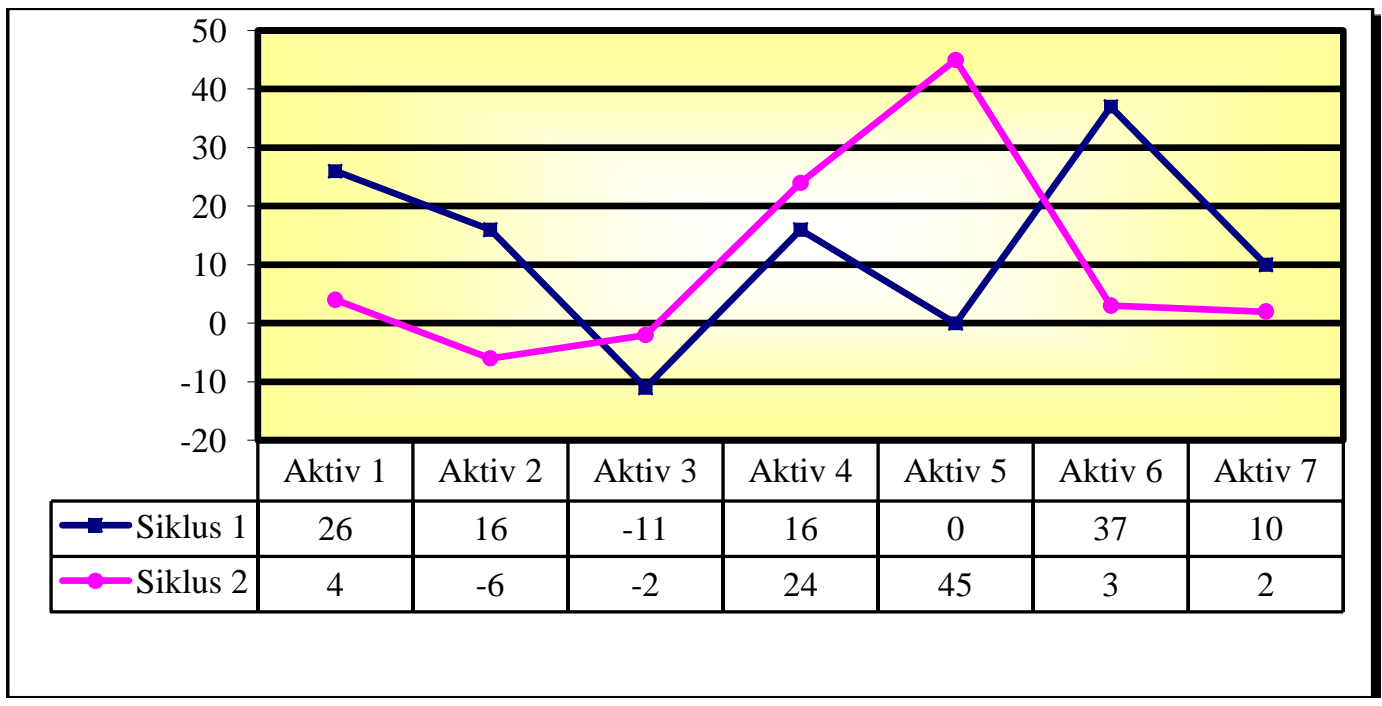

Gambar 1. Grafik Aktivitas Siklus I dengan Siklus II

\section{PEMBAHASAN}

Berdasarkan hasil observasi yang telah dilakukan oleh peneliti dan observer, aktivitas siswa secara garis mengalami peningkatan dari pertemuan 1 dan 2 dari masing-masing siklus. Peningkatan aktivitas tersebut merupakan gambaran yang menunjukkan bahwa model pembelajaran telah dilaksanakan dengan baik.

Dari Gambar 1 di atas dapat dilihat bahwa semua aktivitas siswa yang menjadi indikator dalam penelitian kegiatan belajar dengan menggunakan model pembelajaran word square yang disertai praktik laboratorium telah mengalami peningkatan, dan hanya tiga aspek aktivitas yang tidak mengalami peningkatan, yakni pada kegembiraan siswa dalam belajar dan aktivitas memperhatikan penjelasan guru. Pada siklus I aktivitas siswa yangmemperhatikan penjelasan guru penurunan $11 \%$. Pada siklus II kecepatan dan ketepatan siswa menurun $6 \%$. Siswa yang memperhatikan guru pada siklus II mengalami penurunan $2 \%$ dari. Selain itu aktivitas telah mengalami peningkatan dimulai dari $0 \%$ sampai dengan peningkatan tertinggi yakni $45 \%$.

Aktifitas siswa didalam kelas perlu dilakukan selama proses penelitian, dengan harapan terjadinya peningkatan aktvitas selama proses pembelajaran. jika memperhatikan grafik diatas, dapat terlihat adanya dua aktivitas yang mengalami penurunan. Penurunan persentase aktivitas ini bukan merupakan indicator yang menunjukan turunya 
kwalitas pembelajaran. Penurunan aktivitas yang terjadi lebih mengarah kepada tingginya persentase sebelumnya. Dengan persentase yang tinggi (dalam hal ini > 70\%) akan semakin berat pula mempertahankan apalagi untuk meningkatkanya.

Hal terpenting dalam aktivitas ini adalah kemampuan model pembelajaran yang dapat meningkatkan semangat dan minat siswa selama proses pembelajaran. Dengan semakin tingginya minat dan aktivitas belajar siswa akan berdampak pada tercapainya tujuan pembelajaran. Selain memperhatikan aktivitas yang sudah direncanakan, pengamatan juga digunakan untuk mengetahui aktivitas yang muncul baru muncul dalam pemberlajaran. Aktifitas lain yang muncul diantaranya: 1) kemampuan siswa dalam bertanya 2) Keterampilan proses sains dan lain sebagainya (Wijana, 2011).

Berdasarkan hasil tes yang dilakukan, hasil belajar siswa pada siklus I ke siklus II mengalami peningkatan. Peningkatan hasil belajar ini juga ditunjukkan oleh peningkatan jumlah siswa yang telah tuntas belajar. Peningkatan hasil belajar siswa tersebut dapat dilihat pada Gambar 2.

Berdasarkan grafik data peningkatan hasil belajar siswa di atas, dapat dilihat bahwa persentase siswa yang tuntas belajar dari pra-PTK ke
Siklus 1 mengalami peningkatan sebesar 23,08\%. Pada Siklus 1 persentase siswa yang tuntas belajar hanya mencapai $68,42 \%$, persentase ini belum mencapai target keberhasilan penelitian yait 75\%. Pada Siklus II persentase siswa yang tuntas belajar mencapai 76,92\%. Persentase tersebut mengalami peningkatan dari Siklus I sebesar 8,50\%. Persentase ini telah mencapai target keberhasilan penelitian yaitu $\geq 75 \%$.

Model pembelajaran yang diterapkan dapat memberikan beberapa keuntungan, hal ini sesuai dengan beberapa hal penting dalam kegiatan pembelajaran yang menggunakan model word square yang disertai praktik laboratorium, yaitu 1) siswa lebih bisa berperan aktif dalam pembelajaran. 2) siswa dapat memverifikasi apa yang telah diperoleh selama proses pembelajaran (Wijana, 2011). Hal ini sejalan dengan pengertian bahwa IPA (Sains) bukanlah merupaka kumpulan fakta atau konsep yang harus dihafalkan oleh siswa, dalam arti yang sesungguhnya menunjukkan bahwa IPA memerlukan sebuah proses. Selama proses pemahaman siswa terhadap IPA dapat dibangun dan dikembangkan oleh siswa, maka pemahaman terhadap sains mampu mengarahkan kepada siswa dalam memahami konsep IPA yang telah ada.

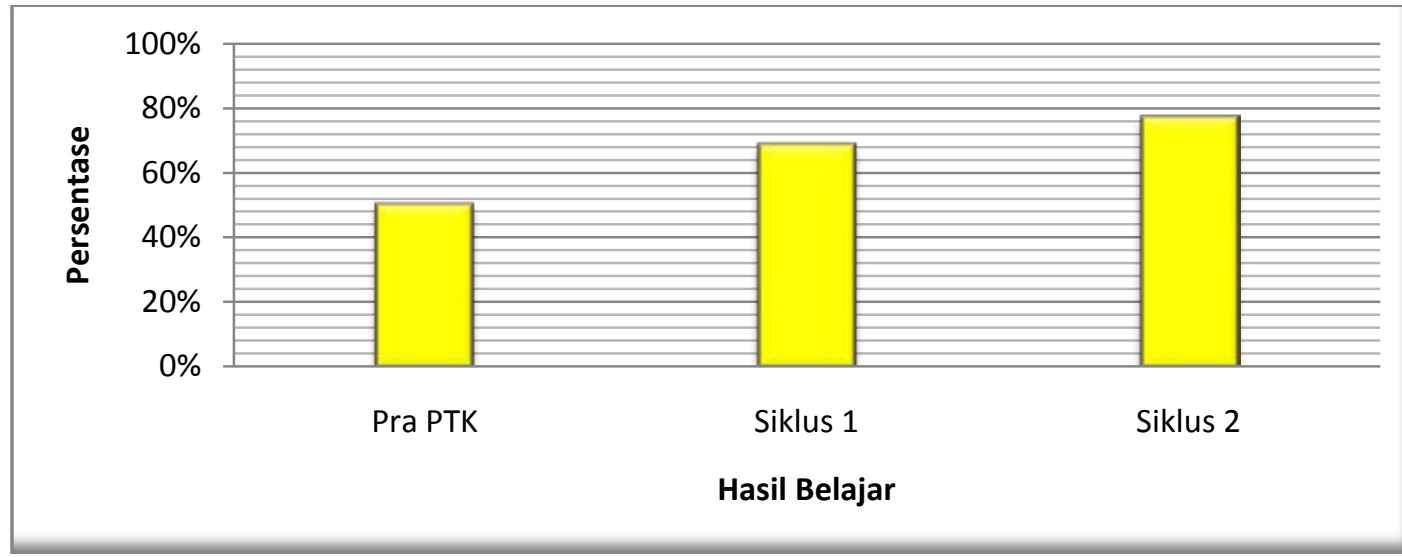


Gambar 2. Grafik Peningkatan Hasil Belajar Siswa

Peningkatan persentase ini dikarenakan pembelajaran yang dilakukan dengan model pembelajaran word square yang disertai praktik laboratorium, karena dapat meningkatkan minat belajar siswa (Deliawati, 2010). Karena dalam pelaksanaannya siswa dapat mengembangkan aktivitas kegembiraan dalam belajar, kecepatan dan ketepatan, memperhatikan penjelasan guru, keterampilan menggunakan alat, kerjasama dalam kelompok, kemauan dan kreativitas siswa serta menumbuhkan sikap kritis dan ingin tahu dari siswa.

\section{KESIMPULAN DAN SARAN}

\section{Kesimpulan}

Berdasarkan hasil penelitian tindakan kelas yang dilakukan dengan menggunakan model pembelajaran word square yang disertai praktik laboratorium dan hasil analisis data hasil penelitian serta pembahasan yang telah dikemukakan, maka dapat disimpulkan bahwa penerapan model pembelajaran word square yang disertai praktik laboratorium dapat meningkatkan Hasil Belajar siswa kelas VIII semester ganjil MTs Al-Asror Sekampung Tahun Pelajaran 2011/2012 pada materi pokok Sistem Kehidupan Tumbuhan.

\section{Saran}

Untuk meningkatkan meningkatkan hasil belajar siswa, peneliti menyarankan kepada guru biologi untuk dapat menggunakan model pembelajaran word square yang disertai praktik laboratorium.

\section{DAFTAR RUJUKAN}

Ainurrahman. 2011. Belajar dan Pembelajaran. Bandung: Alfabeta.

Anonim. 2011. Model Pembelajaran Word Square. http://www1d.wordpress.com/mod el- pembelajaran-word-square/ diakses 27 September 2011

Arikunto, Suharsimi. 2006. Prosedur Penelitian Suatu Pendekatan Praktik. Jakarta: Rineka Cipta. 2006. Prosedur Penelitian Suatu Pendekatan Tematik. Jakarta : PT. Rhineka Cipta.

Depdiknas. 2006. Panduan Penyunan Kurikulum Tingkat Satuan Pendidikan Jenjang Pendidikan Dasar dan Menengah. Disampaikan dalam seminar Nasional Peningkatan Kualitas Guru Mata Pelajaran Umum. Bandung : 10 s./d 12 mei 2011.

Deliawati, Kamisah dkk. (2010). Praktikum IPA Sederhana. Makalah disajikan pada Lokakarya Pelatihan Praktikum IPA Sederhana untuk Menanggulangi Keterbatasan Sarana Laboratorium. Ilmu Pengetahuan dan Teknologi Bagi Masyarakat. Sukadana : Oktober 2010.

Izzudin, Solikhin Abu. 2007. Quantum Tarbiyah Mencetak Kader Serba Bisa. Solo : Bina Insani Press.

Kunandar. 2008. Langkah Mudah Penelitian Tindakan Kelas Sebagai Pengembangan Profesi Guru . Jakarta : Rajagrafindo Persada.

Muhfahroyin. 2009. Telaah Biologi SMP Pengembangan Materi Pokok Berbasis SI dan SKL. Metro. LEMLIT UM Metro Press. 
Rusman, 2011. Model-model Pembelajaran Mengembangkan Profesional Guru. Jakarta : PT. Rajafindo Persada.

S, Suparman. 2010. Gaya Mengajar yang Menyenangkan Siswa. Yogjakarta : Pinus Book Publiser.

Sanjaya, Wina. 1990. Strategi Pembelajaran Berorientasi Standar Proses Pendidikan. Jakarta: Prenada Media Group

Sudjana, N. 1996. Metoda Statistika. Bandung: Tarsito.

Sumintono, Bambang. 2010. http://www.deceng.wordpress.com I diakses tanggal 20 September 2011.

Syah, Muhibbin. Psikologi Belajar. Jakarta : PT. Rajagrafindo Persada.
Syamsuri, I; Sulis, S; Ibrohim; Sofia. 2004. Sains IPA Terpadu (Biologi) SMP Kelas VIII. Jakarta: Erlangga.

Universitas Muhammadiyah Metro. 2003. Pedoman Peulisan Karya Ilmiah. Edisi Revisi. Metro : Um Metro.

Wijana, Eka. 2011. Penerapan Model Belajar Word Square untuk Meningkatkan Hasil Belajar Siswa Pada Pembelajaran Matematika. Skripsi. Cirebon: IAIN Syekh Nurjati.

Wurianingrum, Tri. 2007. Meningkatkan Hasil Belajar Siswa Melalui Metode Observasi yang divariasikan dengan LKS Word Square Pada Materi Klasifikasi Hewan. Skripsi. Semarang: Universitas Negeri Malang. 